\title{
Catalysis Using Metal Oxides with Mixed Ionic -Electronic Conductivity for Clean Energy Electrochemical Systems
}

Su Ha*

Chemical Engineering and Bioengineering Department, Washington State University, USA

*Corresponding author: Su Ha, The Voiland School of Chemical Engineering and Bioengineering, Washington State University, Pullman, USA.

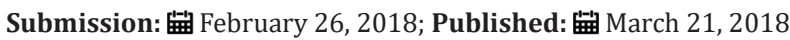

Introduction
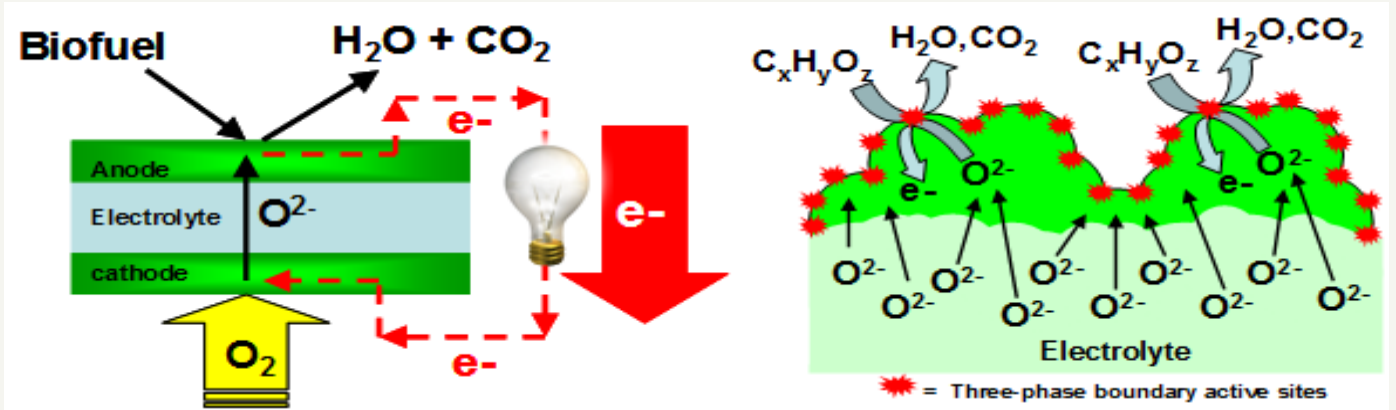

Figure 1: (A) Schematic diagram describing the operating principle of asolid oxide fuel cells (SOFC). Reactions are not stoichiometrically balanced. The bio fuel contains oxygenated hydrocarbons. It is fed to the anode of the SOFC, where it is electrochemically oxidized by combining with lattice oxygen $\left(\mathrm{O}_{2}-\right)$ from the cathode to produce $\mathrm{H}_{2} \mathrm{O}, \mathrm{CO}_{2}$ and electrons. To complete the circuit, these electrons flow through an external electrical line, producing electrical power, and combine with gas phase $\mathrm{O}_{2}$ to produce lattice oxygen at the cathode. (B) The metal oxide anode of a SOFC with mixed conductivity provides a threephase boundary where efficient ion-electron and reactant transports occur in a single phase.

Direct bio-fuel solid oxide fuel cells (SOFCs) can play a key role in reducing greenhouse gases, reducing U.S. dependence on imported oil and moving us toward future energy independence [19]. Direct bio-fuel SOFCs can directly convert the chemical energy of bio-derived fuels into electrical energy as shown in Figure 1(A) $[1,2]$. In order to efficiently operate them, it is critical to develop a high-performance anode that can directly process bio-fuels [14]. Metal oxides with mixed conductivities, which transport both ions and electrons in a single phase, can be used as anodes for this application [5-14]. These oxides provide a three-phase boundary which is the area of contact among between the three phases necessary for electrochemical reactions to occur at the electrode: ion conducting phase, electron conducting phase, and gas phase (see Figure 1B). By balancing and controlling electronic and ionic bulk transport, the surface reaction rates and kinetics can be controlled [15-22]. Although the electrode materials have been used in various electrochemical applications [23-29], the fundamental relationship between ion-electron transport and catalytic activity with oxygenated hydrocarbons is still poorly understood. It is very important to address this scientific gap because high bio-fuel oxidation activity is an essential component of a high-performance direct bio-fuel SOFC. The goal of this review is to summarize the working principle of direct bio-fuel SOFC, its performance limitations using the conventional catalytic materials, and its alternative catalytic materials for mitigating these limitations (especially metal oxides with $\mathrm{MO}_{2}$ structure (where $\mathrm{M}=$ Mo, W, Ru, Re, Os, Ir)).

\section{Literature Reviews}

\section{Molecular structure of bio-fuels}

One main distinction between petroleum fuels and bio-fuels is that petroleum fuels consisted of only carbon and hydrogen atoms while bio-fuels hold additional oxygen-containing functional groups [30-36]. Depending on the source of biomass and the chemical process used for chemical conversion, bio-fuels can have various functional groups and carbon-chain structures [37-42]. The different molecular structures of bio-fuels show different selectivity toward breaking $\mathrm{C}-\mathrm{H}, \mathrm{O}-\mathrm{H}, \mathrm{C}-\mathrm{O}$ and $\mathrm{C}-\mathrm{C}$ bonds, and different interaction with the metal oxide surface [43-47]. Thus, the bio-fuel oxidation activity and selectivity are strongly influenced by the molecular structure of bio-fuels. 


\section{Operating principle of direct bio-fuel SOFC}

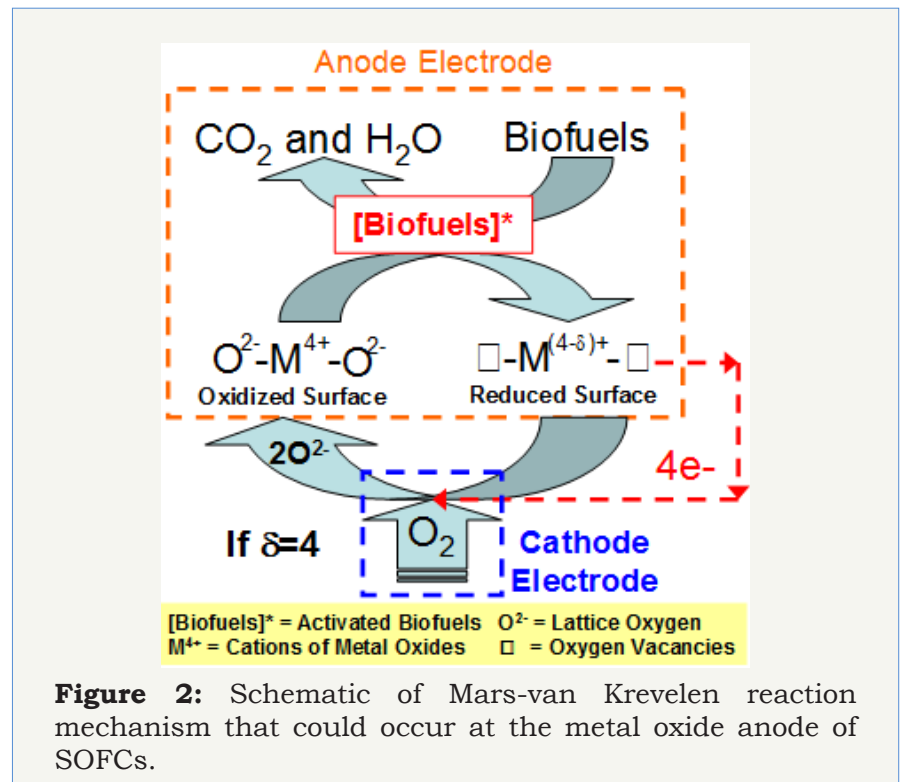

A SOFC is an all-ceramic device that typically operates in the range $700-1000{ }^{\circ} \mathrm{C}$ [1-4]. Unlike low temperature polymer electrolyte membrane-(PEM) fuel cells, SOFCs hold particular promise for their ability to use $\mathrm{CO}$ as a fuel rather than being poisoned by it [48-51]. In addition, SOFCs do not require expensive noble metals to oxidize fuels. For a direct bio-fuel SOFC, the bio-fuels are fed to the anode, while molecular oxygen is fed to the cathode. In the high temperature range of interest to SOFC, it is believed that a Mars-van Krevelen mechanism is a dominant reaction pathway for oxidizing the fuels by reacting them with lattice oxygen from the electrolyte to produce electrons, $\mathrm{CO}_{2}$, and $\mathrm{H}_{2} \mathrm{O}$ (see Figure 2) [52-57]. According to this mechanism, the bio-fuels are first activated by breaking $\mathrm{C}-\mathrm{H}$ or $\mathrm{O}-\mathrm{H}$ bonds $[58,59]$. Typically, there is a strong charge interaction between these activated species and the cat ions of metal oxides $[60,61]$. As a result, the rate of the initial activation step strongly depends on the metallic property of metal oxides. Thus, controlling the metallic property of anode is very important to optimizing their fuel oxidation activity. The activated species are oxidized into $\mathrm{CO}_{2}$ and $\mathrm{H}_{2} \mathrm{O}$ by insertion of lattice oxygen, which creates surface oxygen vacancies and reduces the surface. To continue this redox catalytic cycle, the reduced surface site is reoxidized by releasing electrons via an external circuit to the cathode. In this sense, the lattice oxygen is the only oxygen source available for bio-fuel oxidation in SOFC. Consequently, the mobility and concentration of the lattice oxygen are closely related to the overall bio-fuel oxidation activity and selectivity [62-65]. The electrons generated at the anode combine with molecular oxygen to produce lattice oxygen at the cathode. This lattice oxygen diffuses toward the anode via the electrolyte to fill the vacancy, thereby completing the circuit. The flux of lattice oxygen from the cathode to the anode of SOFC is controlled by its operating cell voltage. The oxidationdegree and functional group of a bio-fuel can also significantly influence its activation step and affect its reaction selectivity [66-70]. Previous studies hypothesized that bio-fuels with a high degree of oxidation would benefit their oxidation activity because they demand less lattice oxygen $[71,72]$.

\section{Previously used catalytic materials in direct SOFCs}

The most important materials problem to be addressed in the development of direct bio-fuel SOFCs is the anode. To operate efficiently for a long period of time, anode catalysts must have high bio-fuel oxidation activity and stability. Nickel-based electrodes have been widely utilized in direct fuel SOFCs [73-75]. Since it is a metal, Ni has a high electrical conductivity. To provide a thermal expansion match with the electrolyte and ionic conductivity to extend the three-phase boundary, $\mathrm{Ni}$ is conventionally mixed with yttria-stabilized zirconia (YSZ) to form a Ni-YSZ metal-ceramic composite (i.e., a cermet) [76]. However, the major disadvantage of the Ni-based electrode arises from its tendency to coke. Above $700^{\circ} \mathrm{C}$, the active sites of $\mathrm{Ni}$ cermets are covered by a filamentous carbon coating [77-79]. To prevent coking, other researchers have replaced $\mathrm{Ni}$ with various metal oxides or mixed metal oxides, which possess high oxygen anion mobility. Due to the availability of lattice oxygen, the formation of coke is significantly retarded, while a high reforming activity for bio-fuels is retained [80-82]. However, the major disadvantage with these approaches to date is that the electronic conductivity of the materials is very low (e.g., $\mathrm{CeO}_{2}$ has conductivity $10 \mathrm{~S} / \mathrm{m}$ at $25{ }^{\circ} \mathrm{C}$ ). Because of the low electronic conductivity, these anodes show a high overpotential that leads to a low power density [76]. The University of Pennsylvania team improved the electronic conductivity of metal oxides by mixing them with catalytically inert transition metals [83]. For example, they replaced the Ni-YSZ anode with a $\mathrm{Cu}-\mathrm{CeO}_{2}-\mathrm{YSZ}$ anode. The $\mathrm{Cu}$ provides excellent electronic conductivity but (unlike $\mathrm{Ni}$ ) it is relatively catalytically inert. $\mathrm{CeO}_{2}$ is used because of its high hydrocarbon oxidation activity, while YSZ provides the high ionic conductivity. This $\mathrm{Cu}-\mathrm{CeO}_{2}$-YSZ anode shows good power density output and stability on various hydrocarbons and oxygenated hydrocarbons $[4,83,84]$. However, this anode has a disadvantage of increased complexity due to the increased number of required components and the requirement that reactions can only happen at the three-phase boundary.

\section{Alternative $\mathrm{MO}_{2}$ catalytic materials in direct SOFCs}

To decrease the complexity of electrode design, it is desired to use a single-phase catalyst that meets all of the anode requirements of direct SOFCs. The commonly suggested materials are the perovskite-structured oxides with a general chemical formula of $\mathrm{ABO}_{3}$ [48,85-87]. However, our research team recently found that metal oxides with mixed conductivity such as $\mathrm{MoO}_{2}$ also possess a very high catalytic oxidation activity toward biodiesel. $\mathrm{MO}_{2}$ (where $\mathrm{M}=\mathrm{Mo}, \mathrm{W}, \mathrm{Ru}, \mathrm{Re}, \mathrm{Os}, \mathrm{Ir}$ ) exhibits an unusual metallic-like electronic conductivity, which is not a common characteristic of most metal oxides [88,89]. Its electronic conductivity is attributed to a relatively high density of states in the valence band [90]. Figure 3 shows the distorted rutile crystal structure of $\mathrm{MO}_{2}$ [91]. As the axial ratio of $\mathrm{MO}_{2}$ decreases, its metal-metal bond distance becomes shorter thereby increasing the number of free valence 
electrons available per bond [92]. Thus, the electronic conductivity of $\mathrm{MO}_{2}$ can be tuned by controlling its axial ratio. The easiest way for controlling $\mathrm{MO}_{2}$ 's axial ratio is by doping it with other $\mathrm{MO}_{2}$ that possesses higher or low axial ratios [93-97]. The axial ratio of $\mathrm{RuO}_{2}$ is 0.69 [98] while that of $\mathrm{MoO}_{2}$ and $\mathrm{WO}_{2}$ is between 1.00 and 1.02 $[99,100]$. As a small amount of $\mathrm{RuO}_{2}$ is doped into either the $\mathrm{MoO}_{2}$ or $\mathrm{WO}_{2}$ crystal structure, the unit cell volume should decrease and thus their electronic conductivity should increase. Similar to many metal oxides, $\mathrm{MO}_{2}$ also has high oxygen anion conductivity $[90,101]$. Its oxygen anion conductivity can be manipulated by controlling its metal-oxygen bond strength. Like its electronic conductivity, its metal-oxygen bond strength can be modified by doping it with other $\mathrm{MO}_{2}$ that possesses different metal-oxygen bond strength [15,102-105]. For example, the metal-oxygen bond of $\mathrm{MoO}_{2}$ is primarily "ionic" while that of $\mathrm{SiO}_{2}$ is "covalent." Consequently, the lattice oxygen mobility of $\mathrm{MoO}_{2}$ decreases by doping it with a small amount of $\mathrm{SiO}_{2}$ [106].

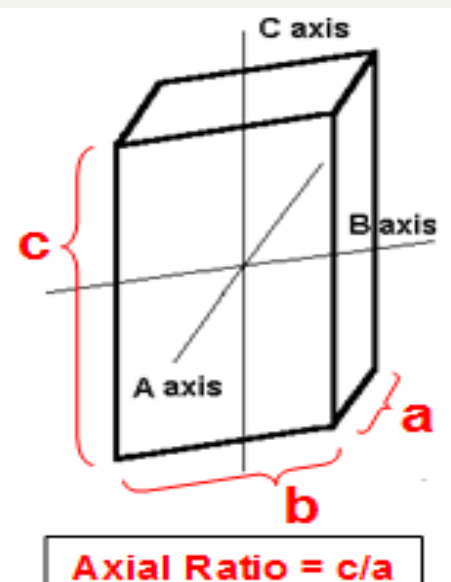

Figure 3: The monoclinic crystal structure of $\mathrm{MO}_{2}$ materials.

The metallic property of $\mathrm{MO}_{2}$ actively breaks various chemical bonds in bio-fuels leading to their high oxidation activity, while their ability to selectively transfer lattice oxygen to the carbon fragments minimizes coke formation during fuel oxidation [90,107-111]. Because of its unique mixed ion-electron conductivity, the threephase boundary (the active electrode area) can be also extended over the entire electrode surface and thus overpotential losses at higher currents can be significantly reduced. Despite these exciting catalytic properties of $\mathrm{MO}_{2}$, there has been a lack of studies to use it as the alternative working electrode material for direct bio-fuel SOFCs.

Redox stability of $\mathbf{M O}_{2}$ : Catalytic materials for efficient direct SOFCs must have both high and stable electrochemical activity under the various redox conditions [112-114]. Depending on the type of cat ion, $\mathrm{MO}_{2}$ will show different phase stability under a range of redox conditions [115-117]. We can increase the stability window of $\mathrm{MO}_{2}$ by doping it with redox stable metal oxides $[15,103-105,107]$. For example, when $\mathrm{RuO}_{2}$ is doped with a small amount of $\mathrm{TiO}_{2}$, its redox stability has been significantly increased
[118-120]. It is believed that $\mathrm{TiO}_{2}$ with a strong metal-oxygen bond decreases the oxygen mobility in $\mathrm{RuO}_{2}$ lattice as they substitute for $\mathrm{Ru}$. A similar tactic has been used to develop a stable $\mathrm{La}_{1-\mathrm{x}} \mathrm{Sr}_{\mathrm{x}} \mathrm{Cr}_{1 \text {. }}$ ${ }_{y} \mathrm{Mn}_{\mathrm{y}} \mathrm{O}_{3}$ (LSCM) perovskite anode catalyst for SOFC, where unstable manganese oxide with a high fuel oxidation activity is atomically mixed with stable chromium oxide [121].

\section{Acknowledgement}

This work was supported financially by the Office of Naval Research (Grant No. N00014-15-1-2416).

\section{References}

1. Milewski J, Lewandowski I (2009) Solid oxide fuel cell fuelled by biofuels. ECS Transactions 25(2): 1031-1040.

2. Sasaki K, Watanabe K, Teraoka Y (2004) Direct-alcohol SOFCs: Current-voltage characteristics and fuel gas compositions. Journal of Electrochemical Society 151(7): A965-A970.

3. Ye X, Huang B, Wang S, Xiong Z, Xiong L, et al. (2007) Preparation and performance of a $\mathrm{Cu}-\mathrm{CeO}_{2}$-ScSZ composite anode for SOFCs running on ethanol fuel. Journal of Power Sources 164(1): 203-209.

4. Restivo T, Leite D, Mello Castanho S (2010) Advanced multi-metallic SOFC development by mechanical alloying route. Materials Science Forum 636-637: 865-873.

5. Park S, Vohs J, Gorte R (2000) Direct oxidation of hydrocarbons in a solid-oxide fuel cell. Nature 404(6775): 265-267.

6. Park S, Gorte R, Vohs J (2000) Applications of heterogeneous catalysis in the direct oxidation of hydrocarbons in a solid-oxide fuel cell. Applied Catalysis A: General 200(1-2): 55-61.

7. Park S, Gorte R, Vohs J (2001) Tape cast solid oxide fuel cells for the direct oxidation of hydrocarbons. Journal of the Electrochemical Society 148 (2001) A443-A447.

8. Lu C, Worrell W, Wang C, Park S, Kim H, et al. (2002) Development of solid oxide fuel cells for the direct oxidation of hydrocarbon fuels. Solid State Ionics 152-153: 393-397.

9. Kim H, Park S, Vohs J, Gorte R (2001) Direct oxidation of liquid fuels in a solid oxide fuel cell. Journal of the Electrochemical Society 148(7): A693-A695.

10. Worrell W (1992) Electrical properties of mixed-conducting oxides having oxygen-ion conductivity. Solid State Ionics 52(1-3): 147-151.

11. Tao S, Irvine J (2002) Optimization of mixed conducting properties of $\mathrm{Y}_{2} \mathrm{O}_{3}-\mathrm{ZrO}_{2}-\mathrm{TiO}_{2}$ and $\mathrm{Sc}_{2} \mathrm{O}_{3}-\mathrm{Y}_{2} \mathrm{O}_{3}-\mathrm{ZrO}_{2}-\mathrm{TiO}_{2}$ solid solutions as potential SOFC anode materials. Journal of Solid State Chemistry 165(1): 12-18.

12. Slater P, Fagg D, Irvine J (1997) Synthesis and electrical characterization of doped perovskite titanates as potential anode materials for solid oxide fuel cells. J Mater Chem 7: 2495-2498.

13. Hui S, A Petric (2002) Evaluation of yttrium-doped $\mathrm{SrTiO}_{3}$ as an anode for solid oxide fuel cells. Journal of the European Ceramic Society 22(910): 1673-1681

14. Gorte R, Vohs J, McIntosh S (2004) Recent developments on anodes for direct fuel utilization in SOFC. Solid State Ionics 175(1-4): 1-6.

15. Gaudet J, Tavares A, Trasatti S, Guay D (2005) Physicochemical characterization of mixed $\mathrm{RuO}_{2}-\mathrm{SnO}_{2}$ solid solutions. Chem Mater 17(6): 1570-1579.

16. Blondeel J, Harriman A, Porter G, Urwin D, Kiwi J (1983) Design, preparation and characterization of ruthenium dioxide/titanium dioxide catalytic surface active in photooxidation of water. J Phys Chem 87(14): 2629-2636 
17. Merino N, Barbero B, Ruiz P, Cadus L (2006) Synthesis, characterization, catalytic activity and structural stability of $\mathrm{LaCo}_{1-\mathrm{y}} \mathrm{Fe}_{\mathrm{y}} \mathrm{O}_{3+\lambda}$ perovskite catalysts for combustion of ethanol and propane. Journal of Catalysis 240(2): 245-257.

18. Ciambelli P, Cimino S, De Rossi S, Lisi L, Minelli G, et al. (2001) $\mathrm{AFeO}_{3}$ ( $\mathrm{A}=\mathrm{La}, \mathrm{Nd}, \mathrm{Sm}$ ) and $\mathrm{LaFe}_{1-\mathrm{x}} \mathrm{Mg}_{\mathrm{x}} \mathrm{O}_{3}$ perovskites as methane combustion and $\mathrm{CO}$ oxidation catalysts: structural, redox and catalytic properties. Applied Catalysis B: Environmental 29(4): 239-250.

19. Weidenkaff A (2004) Preparation and application of nanostructured perovskite phases. Advanced Engineering Materials 6(9): 709-714.

20. Ishihara T (2009) Perovskite oxide for solid oxide fuel cells. London: Springer, pp.7-12.

21. Cordischi D, De Rossi S, Faticanti M, Minelli G, Porta P (2002) LaAl ${ }_{x} \mathrm{Cr}_{\mathrm{x}} \mathrm{O}_{3}$ perovskite-type solid solutions: structural, electronic, magnetic properties and catalytic activity towards $\mathrm{CO}$ oxidation. Phys Chem Chem Phys 4: 3085-3090.

22. Bossche M, McIntosh S (2008) The rate and selectivity of methane oxidation over $\mathrm{La}_{0.75} \mathrm{Sr}_{0.25} \mathrm{Cr}_{\mathrm{x}} \mathrm{Mn}_{1-\mathrm{x}} \mathrm{O}_{3-\delta}$ as a function of lattice oxygen stoichiometry under solid oxide fuel cell anode conditions. Journal of Catalysis 255(2): 313-323.

23. Tao S, Irvine J (2004) Investigation of the mixed conducting oxide ScYZT as a potential SOFC anode material. Journal of the Electrochemical Society 151(4): A497-A503.

24. Ge L, Shao Z, Zhang K, Ran R, Diniz da Ccosta J, et al. (2009) Evaluation of mixed-conducting lanthanum-strontium-cobaltite ceramic membrane for oxygen separation. AIChE Journal 55(10): 2603-2613.

25. Liu J, Zhang Z, Pan C, Zhao Y, Su X, et al. (2004) Enhanced field emission properties of $\mathrm{MoO}_{2}$ nanorods with controllable shape and orientation. Materials Letters 58(29): 3812-3815.

26. Tenne R, Margulis L, Genut M, Hodes G (1992) Polyhedral and cylindrical structure of WS. Nature 360(6403): 444-446.

27. Bach U, Corr, Lupo D, Pichot F, Ryan M (2002) Nanomaterials-based electrochromics for paper-quality displays. Advanced Materials 14(11): 845-848.

28. Yang L, Gao Q Tang Y, Wu Y, Holze R (2008) $\mathrm{MoO}_{2}$ synthesized by reduction of $\mathrm{MoO}_{3}$ with ethanol vapor as an anode material with good rate capability for the lithium ion battery. Journal of Power Sources 179(1): 357-360

29. Malikov I, Mikhailov G (1997) Electrical resistivity of epitaxial molybdenum films grown by laser ablation deposition. Journal of Applied Physics 82(11): 5555-5559.

30. Chien Y, Lu M, Chai M, Boreo F (2009) Characterization of biodiesel and biodiesel particulate matter by TG, TG-MS, and FTIR. Energy \& Fuels 23(1): 202-206.

31. Ragauskas AJ, Williams CK, Davison BH, Britovsek G, Cairney J, et al. (2006) The path forward for biofuels and biomaterials. Science 311(5760): 484-489.

32. Chheda J, Huber G, Dumesic J (2007) Liquid-phase catalytic processing of biomass-derived oxygenated hydrocarbons to fuels and chemicals. Angew Chem Int Ed Engl 46(38): 7164-7183.

33. Petrus L, Noordermeer M (2006) Biomass to bio-fuels, a chemical perspective. Green Chemistry 8: 861-867.

34. Mohan D, Pittman C, Steele P (2006) Pyrolysis of wood/biomass for biooil: a critical review. Energy \& Fuels 20(3): 848-889.

35. Huber G, Chheda J, Barrett C, Dumesic J (2005) Production of liquid alkanes by aqueous-phase processing of biomass-derived carbohydrates. Science 308(5727): 1446-1450.

36. Huber G, Iborra S, Corma A (2006) Synthesis of transportation fuels from biomass: chemistry, catalysts, and engineering. Chem Rev 106(9): 4044-4098.

37. Pinzi S, Garcia I, Lopez Gimenez F, Luque de Castro M, Dorado G, et al. (2009) The ideal vegetable oil-based biodiesel composition: a review of social, economical and technical implications. Energy \& Fuels 23(5): 2325-2341.

38. Refaat A, Attia N, Sibak H, El Sheltawy S, El Diwani G (2008) Production optimization and quality assessment of biodiesel from waste vegetable oil. International Journal of Environmental Science and Technology 5(1): $75-82$

39. Johnson R, Liaw S, Garcia Perez M, Ha S, Lin S, et al. (2009) Pyrolysis gas chromatography mass spectrometry studies to evaluate hightemperature aqueous pretreatment as a way to modify the composition of bio-oil from fast pyrolysis of wheat straw. Energy \& Fuels 23(12): 6242-6252.

40. Boateng A, Weimer P, Jung H, Lamb J (2008) Response of thermochemical and biochemical conversion processes to lignin concentration in alfalfa stems. Energy \& Fuels 22(4): 2810-2815.

41. Lynd L, Weimer P, Pretorius I, Van Zyl W (2002) Microbial cellulose utilization: fundamentals and biotechnology. Microbiol Mol Biol Rev 66(3): 506-577.

42. Weimer P, Dien B, Springer T, Vogel K (2005) In-vitro gas production as a surrogate measure of the fermentability of cellulosic biomass to ethanol. Appl Microbiol Biotechnol 67(1): 52-58.

43. Saunders G, Kendall K (2002) Reactions of hydrocarbons in small tubular SOFCs. Journal of Power Sources 106(1-2): 258-263.

44. McIntosh S, Gorte R (2004) Direct hydrocarbon solid oxide fuel cells. Chem Rev 104(10): 4845-4866.

45. Sasaki K, Watanabe K, Teraoka Y (2004) Direct-alcohol SOFCS: currentvoltage characteristics and fuel gas compositions. Journal of The Electrochemical Society 151(7): A965-A970.

46. Zha S, Moore A, Abernathy H, Liu M (2004) GDC-based low-temperature SOFCs powered by hydrocarbon fuels. Journal of the Electrochemical Society 151(8): A1128-A1133.

47. Saunders G, Kendall J (2004) Formulating liquid hydrocarbon fuels for SOFCs. Journal of Power Sources 131(1-2): 23-26.

48. Vanden Bossche M, McIntosh S (2008) Rate and selectivity of methane oxidation over $\mathrm{La}_{075} \mathrm{Sr}_{025} \mathrm{Cr}_{x} \mathrm{Mn}_{1-\mathrm{x}} \mathrm{O}_{3-\mathrm{delta}}$ as a function of lattice oxygen stoichiometry under solid oxide fuel cell anode conditions. Journal of Catalysis 255(2): 313-323.

49. Su C, Wu Y, Wang W, Zheng Y, Ran R, et al. (2010) Assessment of nickel cermets and $\mathrm{La}_{0.8} \mathrm{Sr}_{0.2} \mathrm{Sc}_{0.2} \mathrm{Mn}_{0.8} \mathrm{O}_{3}$ as solid-oxide fuel cell anodes operating on carbon monoxide fuel. Journal of Power Sources 195(5): 1333-1343.

50. Steele B (1999) Fuel-cell technology: running on natural gas. Nature 400: 619-621.

51. Staniforth J, Ormerod R (2003) Running solid oxide fuel cells on biogas. Ionics 9(5-6): 336-341.

52. Jardiel T, Caldes M, Moser F, Hamon J, Gauthier G, et al. (2010) New SOFC electrode materials: The Ni-substituted LSCM-based compounds $\left(\mathrm{La}_{0.75} \mathrm{Sr}_{0.25}\right)\left(\mathrm{Cr}_{0.5} \mathrm{Mn}_{0.5-\mathrm{x}} \mathrm{Ni}_{\mathrm{x}}\right) \mathrm{O}_{3-\delta}$ and $\left(\mathrm{La}_{0.75} \mathrm{Sr}_{0.25}\right)\left(\mathrm{Cr}_{0.5-\mathrm{x}} \mathrm{Ni}_{\mathrm{x}} \mathrm{Mn}_{0.5}\right) \mathrm{O}_{3-\delta}$. Solid State Ionics 181(19-20): 894-901.

53. Merkle R, Maier J (2008) How is oxygen incorporated into oxides? a comprehensive kinetic study of a simple solid-state reaction with $\mathrm{SrTiO}_{3}$ as a model material. Angew Chem Int Ed Engl 47(21): 3874-3894.

54. De Ridder M, Van Welzenis R, Denier Vander Gon A, Brongersma $\mathrm{H}$ (2002) Subsurface segregation of yttria in yttria stabilized zirconia. Journal of Applied Physics 92(6): 3056-3064.

55. Steele B (1996) Materials for high-temperature fuel cells. Philosophical 
Transactions: Mathematical, Physical and Engineering Sciences 354(1712): 1695-1710.

56. Zhan M, Wang W, Tian T, Chen C (2010) catalytic partial oxidation of methane over perovskite $\mathrm{la}_{4} \mathrm{Sr}_{8} \mathrm{ti}_{12} \mathrm{O}_{38-\delta}$ solid oxide fuel cell (SOFC) anode material in an oxygen-permeable membrane reactor. Energy \& Fuels 24(2): 764-771.

57. Lintz H, Reitzmann A (2007) Alternative reaction engineering concepts in partial oxidations on oxidic catalysts. Catalysis Reviews 49(1): 1-32.

58. Kung H (1989) Transition metal oxides: surface chemistry and catalysis. ( $1^{\text {st }}$ edn.) Elsevier Science Publ, Amsterdam, Netherlands, Europe: 170174.

59. Idriss $H$ (2004) Ethanol reactions over the surfaces of noble metal/ cerium oxide catalyst. Platinum Metals Rev 48(3): 105-115.

60. Spivey J, Roberts G (2004) Catalysis. The Royal Society of Chemistry, Cambridge, England, United Kingdom, Europe: 127-128.

61. Vedrine J (1997) Molecular approach to active sites on metallic oxides for partial oxidation reaction. Studies in Surface Science and Catalysis 110: 61-76.

62. Vedrine J, Coudurier G, Forissier M, Volta J (1985) Catalytic properties of metallic oxides in partial oxidation reactions. Materials Chemistry and Physics 13(3-4): 365-378.

63. Lin W, Lin L, Zhu Y, Xie Y, Scheurell K, et al. (2005) Novel Pd/TiO $-\mathrm{Al}_{2} \mathrm{O}_{3}$ catalysts for methane total oxidation at low temperature and their $0-18$ isotope exchange behavior. Chinese Journal of Chemistry 23(10): 13331338.

64. Ivanov D, Sadovskaya E, Pinaeva L, Isupova L (2009) Influence of oxygen mobility on catalytic activity of La-Sr-Mn-O composites in the reaction of high temperature $\mathrm{N}_{2} \mathrm{O}$ decomposition. Journal of Catalysis 267(1): 5-13.

65. Minh N (1993) Ceramic fuel-cells. Journal of the American Ceramic Society 76(3): 563-588.

66. Sun Y, Cheng J (2002) Hydrolysis of lignocellulosic materials for ethano production: a review. Bioresour Technol 83(1): 1-11.

67. Lee J (1997) Biological conversion of lignocellulosic biomass to ethanol. J Biotechnol 56(1): 1-24.

68. Hahn Hagerdal B, Galbe M, Gorwa Grauslund M, Liden G, Zacchi G (2006) Bio-Ethanol-the fuel of tomorrow from the residues of today. Trends in Biotechnology 24(12): 549-556.

69. Margeot A, Hahn Hagerdal B, Edlund M, Slade R, Monot F (2009) New improvements for lignocellulosic ethanol. Curr Opin Biotechnol 20(3): 372-380.

70. Lin Y, Tanaka S (2005) Ethanol fermentation from biomass resources current state and prospects. Appl Microbiol Biotechnol 69(6): 627-642.

71. Moser B (2009) Comparative oxidative stability of fatty acid alkyl esters by accelerated methods. Journal of the American Oil Chemists' Society 86(7): 699-706.

72. Preece J (2006) Oxygenated hydrocarbon fuels for solid oxide fuel cells. Ph.D. Thesis, University of Birmingham, England, UK.

73. Laosiripojana N, Assabunlrungrat S (2007) Catalytic steam reforming of methane, methanol, and ethanol over Ni/YSZ : The possible use of these fuels in internal reforming SOFC. Journal of Power Sources 163(2): 943951.

74. Cancellier M, Sin A, Morrone M, Caracino P, Sarkar P, et al. (2007) SOFC anodes for direct oxidation of alcohols at intermediate temperatures. ECS Transactions 7: 275-279.

75. Boer B (1998) SOFC anodes: hydrogen oxidation at porous nickel and nickel/yttria-stabilized zirconia cermet electrodes. Ph.D. Thesis, The University Twente, Netherlands, Europe.
76. Sadykov V, Mezentseva N, Bunina R, Alikina G, Lukashevich A, et al (2008) Effect of complex oxide promoters and Pd on activity and stability of $\mathrm{Ni} / \mathrm{YSZ}$ (ScSZ) cermets as anode materials for IT SOFC. Catalysis Today 131(1-4): 226-237.

77. Bartholomew C, Farrauto R (2006) Fundamental of industrial catalytic processes. Wiley, Hoboken, New Jersey, US: 267-274.

78. Cimenti M, Hill J (2009) Direct utilization of liquid fuels in SOFC for portable applications: challenges for the selection of alternative anodes. Energies 2(2): 377-410.

79. Vogler M, Barzan D, Kronemayer H, Schulz C, Horiuchi M, et al. (2007) Direct-Flame solid-oxide fuel cell (DFFC): a thermally self-sustained, air self-breathing, hydrocarbon-operated sofc system in a simple, nochamber setup. ECS Transactions 7(1): 555-564.

80. Fajardo H, Probst L, Carreno N, Garcia I, Valentini A (2007) Hydrogen production from ethanol steam reforming over $\mathrm{Ni} / \mathrm{CeO}_{2}$ nanocomposite catalysts. Catalysis Letters 119(3-4): 228-236.

81. Biswas P, Kunzru D (2008) Oxidative steam reforming of ethanol over $\mathrm{Ni} / \mathrm{CeO}_{2}-\mathrm{ZrO}_{2}$ catalyst. Chemical Engineering Journal 136(1): 41-49.

82. Frusteri F, Freni S, Chiodo V, Donato S, Bonura G, et al. (2006) Steam and auto-thermal reforming of bio-ethanol over $\mathrm{MgO}$ and $\mathrm{CeO}_{2} \mathrm{Ni}$ supported catalysts. International Journal of Hydrogen Energy 31(15): 2193-2199.

83. Gorte R, Park S, Vohs J, Wang C (2000) Anodes for direct oxidation of dry hydrocarbons in a solid-oxide fuel cell. Advanced Materials 12(19): 1465-1469.

84. Atkinson A, Barnett S, Gorte R, Irvine J, Mcevoy A, et al. (2004) Advanced anodes for high-temperature fuel cells. Nat Mater 3(1): 17-27.

85. Fu Q, Tietz F (2008) Ceramic-based anode materials for improved redox cycling of solid oxide fuel cells. Fuel Cells 8(5): 283-293.

86. Wei T, Ji Y, Meng X, Zhang Y (2008) $\mathrm{Sr}_{2} \mathrm{NiMoO}_{(6-\delta)}$ as anode material for $\mathrm{LaGaO}_{3}$ based solid oxide fuel cell. Electrochemistry Communications 10(9): 1369-1372.

87. Huang B, Wang S, Liu R, Ye X, Nie H, et al. (2007) Performance of $\mathrm{La}_{0.75} \mathrm{Sr}_{0.25} \mathrm{Cr}_{0.5} \mathrm{Mn}_{0.5} \mathrm{O}_{(3--\delta)}$ perovskite-structure anode material at lanthanum gallate electrolyte for IT-SOFC running on ethanol fuel. Journal of Power Sources 167(1): 39-46.

88. Bandi A (1990) Electrochemical reduction of carbon-dioxide on conductive metallic oxides. J Electrochem Soc 137(7): 2157-2160.

89. Sasaki T, Soga T, Adachi H (1982) Electronic-structure of molybdenum dioxide calculated by the x-alpha method. Physica Status Solidi B-Basic Research 113(2): 647-655.

90. Marin Flores O, Scudiero L, Ha S (2009) X-ray diffraction and photoelectron spectroscopy studies of $\mathrm{MoO}_{2}$ as catalyst for the partial oxidation of isooctane. Surface Science 603(15): 2327-2332.

91. Callister W (1999) Materials science and engineering: an introduction. Wiley, New York: 38-40.

92. Riga J, Tenret Noel C, Pireaux J, Caudano R, Verbist J (1977) Electronic structure of rutile oxides $\mathrm{TiO}_{2}, \mathrm{RuO}_{2}$ and $\mathrm{IrO}_{2}$ studied by $\mathrm{x}$-ray photoelectron spectroscopy. Physica Scripta 16(5-6): 351-354

93. Marshall A, Haverkamp R (2010) Electrocatalytic activity of $\mathrm{IrO}_{2}-\mathrm{RuO}_{2}$ supported on Sb-Doped $\mathrm{SnO}_{2}$ nanoparticles. Electrochimica Acta 55(6): 1978-1984.

94. Murakami Y, Miwa K, Ueno M, Ito M, Yahikozawa K, et al. (1994) Morphology of ultrafine $\mathrm{RuO}_{2}-\mathrm{IrO}_{2}$ binary oxide particles prepared by a Sol-Gel process. J Electrochem. Soc 141(9): L118-L120.

95. Roginskaya Y, Varlamova T, Goldshtein M, Belova I, Galyamov B, et al. (1991) Formation, structure and electrochemical properties of iridium dioxide-ruthenium dioxide electrodes. Materials Chemistry and Physics 30(2): 101-113. 
96. Shcheglov P, Drobot D, Syrov Y, Maltseva A (2004) Alkoxide route to Reand Mo-based metallic and oxide materials. Inorganic Materials 40(2): 176-183.

97. Doerr M, Feller J, Oppermann H (1996) Coexistent phases and their electrical and structural behaviour in the ternary $\mathrm{Re} / \mathrm{Mo} / 0$ system. Crystal Research and Technology 31(2): 231-241.

98. Chueh Y, Hsieh C, Chang M, Chou L, Lao C, et al. (2007) $\mathrm{RuO}_{2}$ nanowires and $\mathrm{RuO} / \mathrm{TiO}_{2}$ core/shell nanowires: from synthesis to mechanical, optical, electrical, and photoconductive properties. Advanced Materials 19(1): 143-149.

99. Scanlon D, Watson G, Payne D, Atkinson G, Egdell R, et al. (2010) Theoretical and experimental study of the electronic structures of $\mathrm{MoO}_{3}$ and $\mathrm{MoO}_{2}$. J Phys Chem C 114(10): 4636-4645.

100. Gillet M, Ma K, Gillet E (2004) Structure of tungsten oxide nanoclusters. Surface Science 566-568 (Part 1): 383-389.

101. Werfel F, Minni E (1983) Photoemission study of the electronic structure of Mo and Mo oxides. Journal of Physics C: Solid State Physics 16(31): 6091-6100

102. Trasatti S (1994) Electrochemistry of novel materials. Frontiers in Electrochemistry. J Lipkowski, P Ross (Eds.), Wiley VCH Publishers, New York: 207.

103. Trasatti S (1991) Physical electrochemistry of ceramic oxides. Electrochimica Acta 36(2): 225-241.

104. Iwakura C, Inai M, Tamura $\mathrm{H}$ (1979) Foreign metal-doped $\mathrm{SnO}_{2}$ film anodes for oxygen and chlorine evolution. Chemical Letters 8(3): 225228.

105. Iwakura C, Taniguchi Y, Tamura H (1981) Synergism in chlorine evolution on noble metal-doped $\mathrm{SnO}_{2}$ film electrodes. Chemistry Letters 10(5): 689-692.

106. Liang Y, Tracy C, Weisbrod E, Fejes P, Theodore N (2006) Effect of $\mathrm{SiO}_{2}$ incorporation on stability and work function of conducting $\mathrm{MoO}_{2}$. Appl Phys Lett 88(8): 081901

107. Marin Flores O, Turba T, Ellefson C, Wang K, Breit J, et al. (2010) Nanoparticle molybdenum dioxide: A highly active catalyst for partial oxidation of aviation fuels. Applied Catalysis: Environmental 98(3-4): 186-192.

108. Marin Flores O, Turba T, Breit J, Norton G, Ha S (2010) Thermodynamic and experimental study of the partial oxidation of a jet a fuel surrogate over molybdenum dioxide. Applied Catalysis A: General 381(1-2): 18-

109. Marin Flores O, Ha S (2009) Activity and stability studies of $\mathrm{MoO}_{2}$ catalyst for the partial oxidation of gasoline. Applied Catalysis A:
General 352(1-2): 124-132.

110. Marin Flores O, Ha S (2008) Study of the performance of $\mathrm{Mo}_{2} \mathrm{C}$ for isooctane steam reforming. Catalysis Today 136(3-4): 235-242.

111. Tomita A, Tsunekawa K, Hibino T, Teranishi S, Tachi Y, et al. (2006) Chemical and redox stabilities of a solid oxide fuel cell with $\mathrm{BaCe}_{0.8} \mathrm{Y}_{0.2} \mathrm{O}_{3-\alpha}$ functioning as an electrolyte and as an anode. Solid State Ionics 177(33-34): 2951-2956.

112. Tao S, Irvine J (2003) A redox-stable efficient anode for solid-oxide fuel cells. Nat Mater 2(5): 320-323.

113. Sarantaridis D, Atkinson A (2007) Redox cycling of Ni-based solid oxide fuel cell anode: a review. Fuel Cells 7(3): 246-258.

114. Katrib A, Mey D, Maire G (2001) Molybdenum and tungsten dioxides, $\mathrm{XO}_{2}(\mathrm{X}=\mathrm{Mo}, \mathrm{W})$, as reforming catalysts for hydrocarbon compounds. Catalysis Today 65(2-4): 179-183.

115. Kulesza P, Faulkner L (1988) Electrochemical Preparation of electrodes modified with non-stoichiometric mixed-valent tungsten (VI, V) oxides. Journal of Electroanalytical Chemistry 248(2): 305-320.

116. Atanasoska L, Ogrady W, Atanasoski R, Pollak F (1988) The surface structure of $\mathrm{RuO}_{2}$ : a leed, auger and xps study of the (110) and (100) faces. Surface Science 202(1-2): 142-166

117. Fierro S, Kapalka A, Comninellis C (2010) Electrochemical comparison between $\mathrm{IrO}_{2}$ prepared by thermal treatment of iridium metal and $\mathrm{IrO}_{2}$ prepared by thermal decomposition of $\mathrm{H}_{2} \mathrm{IrCl}_{6}$ solution. Electrochemistry Communications 12(1): 172-174.

118. Guo Y, Hu Y, Sigle W, Maier J (2007) Superior electrode performance of nanostructured mesoporous $\mathrm{TiO}_{2}$ (Anatase) through efficient hierarchical mixed conducting networks. Advanced Materials 19(16): 2087-2091.

119. Colomer M, Jurado J (2000) Structural, microstructural, and electrical transport properties of $\mathrm{TiO}_{2}-\mathrm{RuO}_{2}$ ceramic materials obtained by polymeric Sol-Gel route. Chemistry Materials 12(4): 923-930.

120. Trassatti S, OGrady W (1981) Advances in electrochemistry and electrochemical engineering. H Gerisher, C Tobias (Eds.), Wiley, New York: 177.

121. Tao S, Irvine J, Plint S (2006) Methane oxidation at redox stable fuel cell electrode $\mathrm{La}_{0.75} \mathrm{Sr}_{0.25} \mathrm{Cr}_{0.5} \mathrm{Mn}_{0.5} \mathrm{O}_{(3--\delta)}$. J Phys Chem B 110(43): $21771-$ 21776.
Creative Commons Attribution 4.0 International License

For possible submissions Click Here

\section{Submit Article}

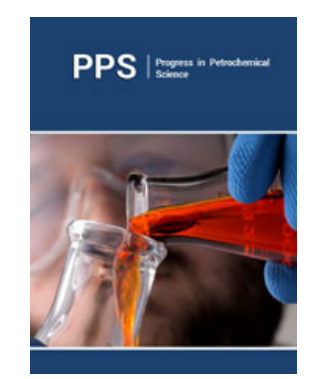

\section{Progress in Petrochemical Science}

Benefits of Publishing with us

- High-level peer review and editorial services

- Freely accessible online immediately upon publication

- Authors retain the copyright to their work

- Licensing it under a Creative Commons license

- Visibility through different online platforms 